\title{
IMPROVING STUDENTS WRITING SKILL BY USING FREE WRITING TECHNIQUE
}

\author{
Mustakim Sagita1, Jamaliah2, Rahimi3 \\ Program Studi Pendidikan Bahasa Inggris \\ Fakultas Keguruan dan Ilmu Pendidikan
}

\begin{abstract}
The aimed of this research is to find out does the use of free writing technique improve students' writing skill or not. The research conducted at SMPN 1 Kembang Tanjong with experimental research design. The population was all of the eighth grade students with the total number of students were 106. The sample was class VIII 1 as experimental class and VIII 2 as control class. The instrument used in pre-test and post-test was a set of written test. Rubric scoring system by Heaton used to analyze the students writing score and independent $\mathrm{T}$-test used to analyze the data. The result of data analysis showed that in pre-test the students at experimental class got mean score 53,5 while at control class got 52,10. In post-test, the students at experimental class who taught writing by using free writing technique got a mean score 78,08 and at control class students who was not got the treatment as in experimental class only got a mean score 57,70. The result of independent T-test, at pretest $t$-count $\quad t$-table $(0,154 \quad 1,685)$ and P-value level of significance $(0,8790,05)$ it means there were no significantly differences between experimental class and control class at pre-test and at posttest $t$-count $t$-table $(3.845 \quad 1,685)$ and P-value level of significance $(0,00 \quad 0,05)$ it means teaching writing by using free writing technique improve significantly the students writing skill. So, the hypothesis was accepted.
\end{abstract}

Key Words: Writing, Free Writing, Descriptive Text

\section{INTRODUCTION}

Language is a tool of communication. There are several forms for communication; the forms are spoken language and written language. The purpose of communication is to send a message from the writer or speaker to the reader or listener.

There are many languages in the world such as English. One of the international language is English. English is the most widely used language by people over the world today. It is learnt as a means of communication at the international level. English is one of the compulsory subjects included in the national curriculum.

Language skill is divided into productive skills and receptive skills. In the curriculum of junior high school, receptive skills cover listening skill and reading skill while productive skills cover speaking and writing skill. Related to this statement, the receptive and productive skills are very important to be taught for all levels of learners from the elementary up to university levels. In writing, many of learners might express their ideas, feelings, thoughts, desires and experiences written to the readers and the listeners, but there are also the learners who cannot express them in written form. This is caused by the learners who still get difficult to develop all of them.

Among the four language skills, "writing is the most difficult skill for second or foreign learners to master" (Richards \& Renandya, 2002: 303). According to Brown (2001: 336) It is because writing is considered as a complex process of putting ideas down on paper to transform thoughts into words. Since the idea or thought is an abstract thing which comes from our mind, it is not easy to transform it into understandable or readable form. The similar definition also stated by Rohman (as cited in McDonald \& McDonald, 2002: 7). He points out that writing is usefully described as a process of putting thoughts into words and words into papers

There are several elements of writing, including grammar, paragraph organization, and vocabulary. Also, there are mechanics of writing which are necessary in making a good writing.

Based on Wadirman (2008: 115) In the second year of junior high school, the basic competency that should be achieved in the writing English subject is that the students have ability to develop and produce written simple functional text in the descriptive text, recount text, and narrative text. Descriptive text is one of the functional texts which is difficult enough to 
be learnt by the students. Descriptive text is a text that describes the features of someone, something, or a certain place.

Descriptive text consists of introduction and description. Introduction is the part of paragraph that introduces the character, and description is the part of paragraph that describes the character. Wardiman, Jahur, \& Djusma (2008) explain that descriptive writing appeals to the senses, so it tells how something looks, feels, smells, testes, and/or sounds. A good description is a word picture. The reader can imagine the object, place, or person in his or her mind. In writing the descriptive text, students often find some difficulties. The students usually feel difficult to organize their ideas. Furthermore, many students made some mistakes and faced difficulties to build and develop their imagination.

Based on the statement above, teachers must be able to organize learning-teaching activities. They have to master the materials, methods and also technique or strategy to make the students understand and apply descriptive writing matters in practice. A good technique can help the students in comprehending and mastering the lesson. One of the teaching failures is caused by an unsuitable method or technique in teaching and learning process. To modify positively the situation of the classroom and to make the teaching-learning process lively, the researcher would like to propose an alternative technique to help the student in improving the skill in writing including improving the knowledge about the elements of writing because those elements make many students get confused in writing. This related to the informal interview that the researcher ever did to the teacher of English in SMPN 1 Kembang Tanjong, she said the students' problems in writing are about lack of vocabulary, grammar, and paragraph organization. Because of that to overcome the students' problem in writing, the teacher need to apply a good technique to create a good class atmosphere and to guide the students to the material that being taught.

Gerlach \& Ely (1980:187) argue "The effective teacher has a multitude of techniques and must be prepared to select the ones which will be most efficient in leading the learner to desire terminal behavior". This statement is supported by Elbow (1998), he states that the best way to improve our writing is to do free writing exercises or free writing technique in writing routinely. Clarkson (2009) explains several advantages of free writing technique, as follow: It makes you more comfortable about writing, It helps you get around your inner critic, the one telling you cannot write, It helps release inner anxiety, It helps you discover topics to write about, It helps you improve your formal writing, It is fun.

Free writing technique means you write whatever comes to your mind and your feelings. It can take you a lot of places. Alice Ozhima and Ann H (1998: 6) said that free writing is a brainstorming activity in which you write freely about the topic. Free writing is a prewriting technique in which a person writes continuously for a set period of time without referring to spelling, grammar, or topic. It produces raw, often unusable material, but helps writers overcome blocks of apathy and self-criticism. This statement does not mean the students will not care to the elements of writing, such as good organization, spelling, grammar, and vocabulary.

Related to this statement, the researcher used free writing technique to be applied in teaching writing especially in writing descriptive paragraph. The researcher concluded that the aim of this technique is to help the students to be easy to get ideas and to give motivation for students such as always practice even though it just spends several minutes. Through this technique, the researcher expected the students to be able to have a new side of thinking about a simple way which might help them to write easily.

To summarize, there are many elements in writing such as grammar, idea, organization, etc. Some of students feel confious about it so they cannot produces the written, because of that the researcher try to apply Free writing technique to help the eight grade students of SMPN 1 Kembang Tanjong in improving their writing skill especially in writing descriptive paragraph even it does not mean the student will not care to the elements of writing at all. Based on the explanation above, the researcher formulated the research as follows: "Does the use of free writing technique improve student's writing skill at the eighth grade students of SMPN 1 Kembang Tanjong?'”. It was to verify that free writing technique improve the students writing skill at the eighth grade students of SMPN 1 Kembang Tanjong. 


\section{METHODOLOGY}

The researcher was apply an experimental research design. The sample consist of two classes: experimental and control class. The researcher gave pre-test and post-test to both of classes, but treatment applied only to the experimental class. The design of this research is proposed by Hatch and Farhady (1982:22) as follows:

$$
\begin{aligned}
& \mathrm{G} 1=\mathrm{T} 1 \mathrm{X} \mathrm{T} 2 \\
& \mathrm{G} 2=\mathrm{T} 1 \quad \mathrm{~T} 2
\end{aligned}
$$

$\mathrm{G} 1=$ experimental class

$\mathrm{G} 2=$ control class

$\mathrm{T} 1=$ pre test for experimental/control class

$$
\mathrm{T} 2=\text { post test for }
$$

experimental/control class

$$
\mathrm{X} \quad=\text { treatment }
$$

This study conducted at SMP Negeri 1 Kembang Tanjong. The school is located at $\mathrm{Jl}$. Tanah Lapang, Kembang Tanjong. The reason of choosing this school was considering of the problems occurred in that school based on the writer's observation at informal interview.

The population of this research was the eight grade students of SMP Negeri 1 Kembang Tanjong as the population. It consists of five classes. They are VIII 1, VIII 2, VIII 3, VIII 4 and VIII 5. Each class consists of 15 up to 20 students. The total number of the population is 106. Because this study used the experimental class and control class so the researcher choosed VIII 1 and VIII 2 as sequential class by using non-probability sampling. Sugiyono (2006: 95) state that non-probability sampling is a technique in establish the sample without giving the same chance to the population to be a sample because of any reason such as a limitation time, and budget. The sample will be choosen based on researcher judgment.

The researcher used one kind of research instrument to collect the data, namely test or a set of written test. A set of written test was give to know the student's achievement in writing skill before and after treatment, the students were gave a topic and wrote two paragraphs on the blank paper based on the topic that was given. After the student do the written test the researcher check the paper and corrected it. The researcher focused on four elements of writing in evaluating the test: content, organization, vocabulary and grammar. Every element would be scoring $1-4$, based on the students writing ability.

The study employed multiple data gatherings over an eight-meeting period. The researcher was meet the class two times a week. The methods were used in this research was qualitative in nature. The researcher conducted pre-test and post-test. Pre-test was give in the first meeting in order to see how far the student's ability in writing skill before the researcher teach them by using free writing technique.In the last meeting, post-test was give in order to know if there were some improvements of student's ability in writing skill especially in writing descriptive paragraph after using free writing technique.

After the pre-test and post-test at experimental and control class, the researcher checked the students paper test and gave the score based on their result. The scoring was using rubric scoring with the point level each elements were 1-4. There were four elements that's evaluated by researcher: content, organization, vocabulary, and grammar.

After that all of the point that students got (the maximum score were sixteen) were multiple with 6,25 to got 100 . Then, the data of students scoring were distributed into table: pre-test table, and post-test table. At last the data were analyzed by using Independent T-Test. To analyze the result of the student's writing, the

\begin{tabular}{|c|c|c|}
\hline $\begin{array}{l}\text { Compo } \\
\text { nents of } \\
\text { Writing }\end{array}$ & Scores & Indicators \\
\hline Content & $\begin{array}{l}4 \\
3 \\
2 \\
1\end{array}$ & $\begin{array}{l}\text { Relevant to the topic } \\
\text { and easy to understand } \\
\text { rather relevant to the } \\
\text { topic and easy to } \\
\text { understand relevant to } \\
\text { the topic but is not quite } \\
\text { easy to understand quite } \\
\text { relevant to the topic but } \\
\text { is not quite easy to } \\
\text { understand }\end{array}$ \\
\hline $\begin{array}{l}\text { Organiz } \\
\text { ation }\end{array}$ & $\begin{array}{l}4 \\
3 \\
2 \\
1\end{array}$ & $\begin{array}{l}\text { most of the sentences } \\
\text { are related to the main } \\
\text { idea } \\
\text { some sentences are } \\
\text { related to the main idea } \\
\text { few sentences related to } \\
\text { the main idea } \\
\text { the sentences are }\end{array}$ \\
\hline
\end{tabular}
researcher used rubric scoring system by Heaton (1989: 145-156).

Table 1 Analytical scoring rubric adapted from Weigle (Sara. 2002: 166) 


\begin{tabular}{|c|c|c|}
\hline & & unrelated to each other \\
\hline \multirow{8}{*}{$\begin{array}{l}\text { Vocabu } \\
\text { lary }\end{array}$} & 4 & \multirow{8}{*}{$\begin{array}{l}\text { a few errors in choice of } \\
\text { words, spelling and } \\
\text { punctuation } \\
\text { some errors in choice of } \\
\text { words, spelling and } \\
\text { punctuation } \\
\text { occasional errors in } \\
\text { choice of words, } \\
\text { spelling and punctuation } \\
\text { frequent errors in choice } \\
\text { of words, spelling and } \\
\text { punctuation }\end{array}$} \\
\hline & 3 & \\
\hline & 2 & \\
\hline & \multirow{5}{*}{1} & \\
\hline & & \\
\hline & & \\
\hline & & \\
\hline & & \\
\hline \multirow{6}{*}{$\begin{array}{l}\text { Gramm } \\
\text { ar }\end{array}$} & 4 & \multirow{6}{*}{$\begin{array}{l}\text { a few grammatical } \\
\text { inaccuracies } \\
\text { some grammatical } \\
\text { inaccuracies } \\
\text { numerous grammatical } \\
\text { inaccuracies } \\
\text { frequent grammatical } \\
\text { inaccuracies }\end{array}$} \\
\hline & 3 & \\
\hline & 2 & \\
\hline & 1 & \\
\hline & & \\
\hline & & \\
\hline
\end{tabular}

In terms of deep data analysis, the researcher used T-test in order to look for the differences score between experimental and control class. According to Sudjana (1992: 239) T-test can be used to examine two differences groups or two similarities of groups by using equivalent means two groups.

$$
(t)=\frac{\overline{\mathrm{X}}_{1}-\overline{\mathrm{X}}_{2}}{\sqrt{\left[\frac{S D 1}{n 1}\right]^{2}+\left[\frac{S D 1}{n 1}\right]^{2}}}=
$$

Where :

t: The significance difference between control and experimental class.

$\overline{\mathrm{X}}_{1}$ : The Mean of experimental class.

$\overline{\mathrm{X}}_{2}$ : The Mean of control class.

$S D_{1}$ : The standard deviation of experimental class.

$\mathrm{SD}_{2}$ : The standard deviation of control class.

$n_{1}$ : The number of sample of experimental class.

$n_{2}$ : The number of sample of control class.

To analize the data by using t-test above, the researcher also used some statistical formula. The data from both classes were distribute to the distribution frequency table. Then, the data has to calculate with some steps of the statistical formula.

Hypothesis verification is used in order to know the result of this research are tenable or untenable. In verifying the hypothesis of this research, I used the level of significance is: (Sudjana, 1996:239) $\alpha=0,05$ and $\mathrm{df}=(\mathrm{n} 1+\mathrm{n} 2$ -2) with criteria as follow: Acceptable $=\mathrm{Ha}$, if T-table is positive, $t$-count $t$-table and if $\mathrm{T}$ table is negative, $\mathrm{t}$-count $\mathrm{t}$-table or the Ha also acceptable if $\mathrm{P}$-value level of significance.

\section{FINDINGS}

The pretest was conducted on Thursday, July 20th 2017. In pretest, the students assigned to write descriptive paragraph consisting of two paragraphs based on the topic that given by the writer about the classroom, every student allowed to write everything related to their classroom. The following was the table of the pre-test results of experimental class and control class.

Table 2

The result of pre-test students' writing score

\begin{tabular}{|c|c|c|c|c|}
\hline No & $\begin{array}{c}\text { Students } \\
\text { Number } \\
\text { (experim } \\
\text { ental } \\
\text { Class) }\end{array}$ & $\begin{array}{l}\text { Pre- } \\
\text { Test }\end{array}$ & $\begin{array}{c}\text { Students } \\
\text { Number } \\
\text { (control } \\
\text { Class) }\end{array}$ & $\begin{array}{l}\text { Pre- } \\
\text { Test }\end{array}$ \\
\hline 1 & $\mathrm{~S} 1$ & 50 & S1 & 25 \\
\hline 2 & S2 & $87,5^{*}$ & S2 & 37,5 \\
\hline 3 & S3 & $68,75^{*}$ & S3 & $75^{*}$ \\
\hline 4 & S4 & 62,5 & S4 & 50 \\
\hline 5 & S5 & $75 *$ & S5 & 62,5 \\
\hline 6 & S6 & 37,5 & S6 & $68,5^{*}$ \\
\hline 7 & S7 & 37,5 & S7 & 37,5 \\
\hline 8 & S8 & 25 & S8 & $87,5^{*}$ \\
\hline 9 & S9 & 43,75 & S9 & 43,75 \\
\hline 10 & $\mathrm{~S} 10$ & $68,75^{*}$ & S10 & 62,5 \\
\hline 11 & S11 & $75^{*}$ & S11 & $75^{*}$ \\
\hline 12 & S12 & 37,5 & S12 & $75^{*}$ \\
\hline 13 & S13 & 25 & S13 & $75^{*}$ \\
\hline 14 & S14 & $75^{*}$ & S14 & 43,75 \\
\hline 15 & S15 & $75^{*}$ & S15 & 25 \\
\hline 16 & S16 & 25 & S16 & 50 \\
\hline 17 & S17 & 43.75 & S17 & 37,5 \\
\hline 18 & S18 & 62,5 & $\mathrm{~S} 18$ & 43,75 \\
\hline 19 & S19 & 37,5 & S19 & 37,5 \\
\hline 20 & S20 & 43,75 & S20 & 25 \\
\hline
\end{tabular}

Note: *) students who passed the Minimum Mastery Criterion (KKM) sixty eight (68)

The data of pre-test (experimental class and control class) presented in the table of interval relative frequency as follows: 
Table 3

The Interval Frequency of Pre-Test Data(Experimental Class)

\begin{tabular}{|c|c|c|c|}
\hline No & $\begin{array}{c}\text { Class } \\
\text { Interval }\end{array}$ & $\begin{array}{c}\text { F. } \\
\text { Absolute }\end{array}$ & $\begin{array}{c}\text { F. } \\
\text { Relative }\end{array}$ \\
\hline 1 & $0-67$ & 13 & $65 \%$ \\
\hline 2 & $68-100$ & 7 & $35 \%$ \\
\hline \multicolumn{2}{|c|}{ Jumlah } & 20 & $100 \%$ \\
\hline
\end{tabular}

The table 3 above showed that 13 students were in interval 0-67 with percentage $65 \%$, and 7 students in interval 68-100 with the percentage $35 \%$, that was mean most of students at experimental class $(65 \%)$ had difficulty in writing skill.

Table 4

The Interval Frequency of Pre-Test Data(control class)

\begin{tabular}{|c|c|c|c|}
\hline No & $\begin{array}{c}\text { Class } \\
\text { Interval }\end{array}$ & F. Absolute & $\begin{array}{c}\text { F. } \\
\text { Relative }\end{array}$ \\
\hline 1 & $68-100$ & 6 & $30 \%$ \\
\hline 2 & $0-67$ & 14 & $70 \%$ \\
\hline \multicolumn{2}{|r|}{ Jumlah } & 20 & $100 \%$ \\
\hline
\end{tabular}

The table 4.3 above showed that 14 students were in interval $0-67$ with percentage $70 \%$, and 7 students in interval 68-100 with the percentage $30 \%$, that was mean most of students at control class $(70 \%)$ had difficulty in writing skill as the students in experimental class.

Based on the result above the researcher concluded that in pretest, There were only seven students or $35 \%$ of the students who got the score above the Minimum Mastery CriterionKriteria Ketuntasan Minimal (KKM) at experimental class and six students or $30 \%$ at control class meanwhile the other 27 students were below that criterion. From that analyzing, it could be seen that almost of the eighth grade students' of SMPN 1 Kembang Tanjong writing descriptive paragraph was still very low and had difficulty in writing skill. So, it needs to find out the solution to overcome this problem.

The post-test was conducted on Tuesday, August 15th 2017. Post-test was conducted to both of experimental class and control class with the same kind of test and also same topic even the treatment just given to experimental class. In post-test, the students assigned to write descriptive paragraph consisting of two paragraphs about the description of their house. The following was the table of the post-test results of experimental class and control class.

Table 5

The result of post-test students' writing score

\begin{tabular}{|l|c|c|c|c|}
\hline No & $\begin{array}{c}\text { Students } \\
\text { Number } \\
\text { experime } \\
\text { ntal } \\
\text { Class) }\end{array}$ & $\begin{array}{c}\text { Post- } \\
\text { Test }\end{array}$ & $\begin{array}{c}\text { Student } \\
\text { S } \\
\text { Number } \\
\text { control } \\
\text { Class) }\end{array}$ & $\begin{array}{c}\text { Post- } \\
\text { Test }\end{array}$ \\
\hline 1 & S1 & $87,5^{*}$ & S1 & 37,5 \\
\hline 2 & S2 & $75^{*}$ & S2 & 50 \\
\hline 3 & S3 & $75^{*}$ & S3 & $87,5^{*}$ \\
\hline 4 & S4 & $75^{*}$ & S4 & 62,5 \\
\hline 5 & S5 & $93,75^{*}$ & S5 & 62,5 \\
\hline 6 & S6 & $75^{*}$ & S6 & $75^{*}$ \\
\hline 7 & S7 & $68,75^{*}$ & S7 & 50 \\
\hline 8 & S8 & 62,5 & S8 & $87,5^{*}$ \\
\hline 9 & S9 & $87,5^{*}$ & S9 & 50 \\
\hline 10 & S10 & $93,75^{*}$ & S10 & 62,5 \\
\hline 11 & S11 & $100^{*}$ & S11 & $68,75^{*}$ \\
\hline 12 & S12 & 62,5 & S12 & $81,25^{*}$ \\
\hline 13 & S13 & 50 & S13 & $75^{*}$ \\
\hline 14 & S14 & $93,75^{*}$ & S14 & 43,75 \\
\hline 15 & S15 & $87,5^{*}$ & S15 & 25 \\
\hline 16 & S16 & $100^{*}$ & S16 & 50 \\
\hline 17 & S17 & 62,5 & S17 & 50 \\
\hline 18 & S18 & $93,75^{*}$ & S18 & 50 \\
\hline 19 & S19 & 50 & S19 & 43,75 \\
\hline 20 & S20 & 62,5 & S20 & 37,5 \\
\hline
\end{tabular}

Note: *) students who passed the Minimum Mastery Criterion (KKM) sixty eight (68)

The data of post-test (experimental class and control class) presented in the table of interval relative frequency as follows:

Table 6

The Interval Frequency of Post-Test Data (Experimental Class)

\begin{tabular}{|c|c|c|c|}
\hline No & Class Interval & $\begin{array}{c}\text { F. } \\
\text { Absolute }\end{array}$ & $\begin{array}{c}\text { F. } \\
\text { Relative }\end{array}$ \\
\hline 1 & $0-67$ & 6 & $30 \%$ \\
\hline 2 & $68-100$ & 14 & $70 \%$ \\
\hline \multicolumn{2}{|c|}{ Jumlah } & 20 & $100 \%$ \\
\hline
\end{tabular}

The table 6 above showed that 6 students were in interval 0-67 with percentage $30 \%$, and 14 students in interval 68-100 with the percentage $70 \%$. 
Table 7

The Interval Frequency of Post-Test Data (Control Class)

\begin{tabular}{|c|c|c|c|}
\hline No & $\begin{array}{c}\text { Class } \\
\text { Interval }\end{array}$ & $\begin{array}{c}\text { F. } \\
\text { Absolute }\end{array}$ & $\begin{array}{c}\text { F. } \\
\text { Relative }\end{array}$ \\
\hline 1 & $0-67$ & 14 & $70 \%$ \\
\hline 2 & $68-100$ & 6 & $30 \%$ \\
\hline \multicolumn{2}{|r|}{ Jumlah } & 20 & $100 \%$ \\
\hline
\end{tabular}

The table 7 above showed that 14 students were in interval 0-67 with percentage $30 \%$, and 6 students in interval 68-100 with the percentage $70 \%$.

Based on the result of the posttest, the data showed that. The percentage of students who got the score above the Minimum Mastery Criterion- Kriteria Ketuntasan Minimal (KKM) at experimental class is $70 \%$ and $30 \%$ at control class, it means there were the significant improvement of mean score at experimental class who got the treatment in teaching writing with free writing technique that 77,8 then the control class who did not get the treatment and only got 57,5. The percentage of students at experimental class who got the score above the Minimum Mastery Criterion- Kriteria Ketuntasan Minimal (KKM) (14 students) was also increased after the implementation of free writing technique in teaching descriptive paragraps. Whereas, there were no improvement of the percentage score above the Minimum Mastery Criterion- Kriteria Ketuntasan Minimal (KKM) at control class. It means the free writing technique that's was apply to experimental class to improve the students skill in writing descriptive text was success as showed at the percentage of sudents who got score above the Minimum Mastery Criterion- Kriteria Ketuntasan Minimal (KKM) increased from $35 \%$ to $70 \%$.

The hypothesis verification is aimed at prooving that the story map technique can improve the studentse ability in writing descriptive text (Sudjana, 1996: 239 ). So, in this part, the researcher would like to verify it by using formula as follows:

$$
(t)=\frac{\overline{\mathrm{X}}_{1}-\overline{\mathrm{X}}_{2}}{\sqrt{\left[\frac{S D 1}{n 1}\right]^{2}+\left[\frac{S D 1}{n 2}\right]^{2}}}=
$$

After testing the hypothesis of this research by using t-test, it is found the data as follows:
A. The Analysis result of experimental and control class Pretest data

Table 7

The Result of Testing Hyphothesis

\begin{tabular}{|c|c|c|c|c|c|}
\hline $\mathrm{N}$ & df & $\begin{array}{c}\mathrm{T}- \\
\text { Count }\end{array}$ & $\begin{array}{c}\mathrm{T}- \\
\text { Table }\end{array}$ & $\begin{array}{c}\text { P- } \\
\text { Value }\end{array}$ & $\begin{array}{c}\text { Signifi } \\
\text { cance } \\
\text { Level }\end{array}$ \\
\hline 40 & 38 & 0,154 & I.685 & 0,879 & 0,05 \\
\hline
\end{tabular}

From the result above, the researcher found that t-count $(0,154)$ with the degree of freedom $=(n 1+n 2-2)=(20+20-2)=38$, based on the degree of freedom got the t-table (1.685). P-value of pretest data 0,879 , the writer used level significance $\alpha 0,05$. Based on that all result the researcher concluded that the value of t-count t-table $(0,154 \quad 1,685)$ and P-value level of significance $(0,8790,05)$ it can be seen there were no differences between experimental class and control class pretest score in writing descriptive text before applied the free writing technique.

B. The Analysis result of experimental and control class posttest data

Table 8

The Result of Testing Hyphothesis

\begin{tabular}{|c|c|c|c|c|c|}
\hline N & df & $\begin{array}{c}\text { T- } \\
\text { Count }\end{array}$ & $\begin{array}{c}\text { T- } \\
\text { Table }\end{array}$ & $\begin{array}{c}\text { P- } \\
\text { Value }\end{array}$ & $\begin{array}{c}\text { Signific } \\
\text { ance } \\
\text { Level }\end{array}$ \\
\hline 40 & 38 & 3.845 & I.685 & 0,00 & 0,05 \\
\hline
\end{tabular}

From the result above, the researcher found that t-count (3.845) with the degree of freedom $=(n 1+n 2-2)=(20+20-2)=38$, based on the degree of freedom got the t-table (1.685). P-value of posttest data 0,00 , the writer used level significance $\alpha 0,05$. Based on that all result the writer concluded that the value of $\mathrm{t}$ count t-table $(3.845 \quad 1,685)$ and P-value level of significance $(0,00 \quad 0,05)$ it was mean there was the differences between experimental class and control class posttest score in writing descriptive text after applied the free writing technique (for experimental class) because of that writing descriptive text by using free writing technique can improve significantly the student's ability. It means that, the hypothesis of this research was accepted. 
The improvement of students at experimental class score also identified at the formula :

$$
\begin{aligned}
& P=\frac{y 1-y}{y} \times 100 \% \\
& P=\frac{78,08-53,05}{53,05} \times 100 \% \\
& P=47 \%
\end{aligned}
$$

It means that there was 25 points or $47 \%$ of mean score increased after the treatment was give to experimental class.

\section{DISCUSSION}

Writing is a part of language learning. The mastery of English writing needs to improve and support by the other language skills (reading, speaking and listening). Most of writer especially the student got some difficulties in writing because they really worried about the elements of writing, it was make they could not produce the written well because of that the teacher should have a good technique in teaching writing.

This study intends to answer research question "does free writing technique improve students writing skill?" and based on the result of the research showed that there were some improvements of students writing skill after the technique applied in teaching learning process. By using free writing technique in teaching writing, the writer allowed the students to express their idea without worried about the elements of writing, but after a task that's gave in every meeting (to experimental class) the writer corrected the students tasks and explained them about the elements one by one.

After the treatment the students could produced a good paragraph with a good content. They could also make a story in a good organization and paragraphing according to the generic structure of descriptive text. Besides, the students could apply the appropriate tense in their writing and also a good vocabulary then before. In this action researcher gave enough opportunity to write, the teaching learning focused more on writing skill. Through this action, the students could have more practices in writing descriptive texts using free writing technique. They could create a better writing.

The results of the test also support the positive improvements; the mean score of the post-test done in the end was 78,08 . It increased 25 points from the mean score of pre-test which was conducted before the treatment. It could be said that there was an improvement in students' writing skill. Practically, the use of free writing technique is an appropriate teaching technique which can be implemented in classroom.

The action was success to attract the students' attention and success on improving students' writing skill, but there were still some weakness. The goal of using free writing technique to improve students writing skill especially in writing descriptive text was successfully achieved.

\section{CONCLUSION AND SUGGESTION}

Based on the findings of the study, the use of free writing technique was believed to be effective in improving students' writing ability. The free writing technique encouraged students to generate ideas in writing the descriptive text. The improvement of students skill in writing descripyive paragraph proved with the result of writing test :

in pre-test the students at experimental class got mean score 53,05 and control class 52,10 while only seven students at experimental class got a score above the Minimum Mastery Criterion- Kriteria Ketuntasan Minimal (KKM) or only $35 \%$ and at control class only six students who got a score above Minimum Mastery Criterion- Kriteria Ketuntasan Minimal (KKM) or only $30 \%$.

In post-test after the treatment, the students at experimental class who taught writing by using free writing technique got a mean score 78,08 and control class students who did not got the treatment only got a mean score 57,70 , while the students at experimental class who got a score above Minimum Mastery Criterion- Kriteria Ketuntasan Minimal (KKM) increased from only seven students to fourteen students or from $35 \%$ increased to $70 \%$ but at control class who did not apply the free writing technique in teaching writing there were no improvement of the students who got a score above Minimum Mastery Criterion- Kriteria Ketuntasan Minimal (KKM), it was still $30 \%$ as in pretest.

It also supported by independent $\mathrm{T}$-test analysis, at pretest the analysis result were the data t-count t-table $(0,154 \quad 1,685)$ and $\mathrm{P}$ value level of significance $(0,879 \quad 0,05)$ it was mean there were no significantly differences between experimental class and control class pretest score in writing descriptive text before applied the free writing technique. At posttest 
data the result were t-count t-table $(3.845$ $1,685)$ and P-value level of significance $(0,00$ $0,05)$ it was mean there was the differences between experimental class and control class posttest score in writing descriptive text after applied the free writing technique (for experimental class) because of that writing descriptive text by using free writing technique improve significantly the student"s ability. It means that, the hypothesis of this research was accepted.

After conducting the research, the researcher proposes suggestions for the English teacher, and other researchers. The teacher should more creative in choosing technique, methods or anything else before starting the writing learning process. It is better for the teacher to provide the students with activities that are motivating for them, especially by using an appropriate technique such as the use of free writing technique. The teacher also could use some media and other exposures, because sometimes writing can be exhausting for them. For other researchers that are interested in the same field are recommended to continue and improve this case study in order that to find any else innovation and efforts to improve students' writing skill by using free writing technique. To make the teaching and learning process to be more enjoyable is to design the techniques and activities should be more creative and enjoyable for students.

\section{REFERENCES}

Brown, H.D. 2001. Teaching by Principles: An Interactive Approach to Language Pedagogy, Second Edition. San Fransisco: Addison Wesley Longman, Inc.

Gerlach, V. \& Ely, D. (1980). Teaching and Media: A Systematic Approach. New Jersey: Prentice-Hall. Inc Company.

Hatch, E and Farhady H. 1982. Research Design and Statistics for Applied Linguistic. Rowley: Newbury House Publisher Inc

McDonald, C.R. and McDonald, R.L. 2002. Teaching Writing. America: Southern Illinois University Press.
Ozhima. Alice and Ann Houge. 1998. Writing (Academic Writing). New York : Longman.

Richards, J.C., and Renandya, W. A.. 2002. Methodology in Language Teaching: An Anthology of Current Practice. Cambridge: Cambridge University Press.

Sara Cushing Weigle. 2002. Assessing Writing. Cambridge: Cambridge niversity

Sugiyono. 2006. Metode Penelitian Kuantitatif, Kualittif, dan R\&D. Bandung: Alfabeta

Sudjana. 1996. Metode Statistika. Jakarta: Erlangga

Wardiman, A, Jahur, M, \& Djusma, S. 2008. English in Focus for Grade VII Junior High School (SMP/MTS). Jakarta: Pusat Perbukuan Departemen Pendidikan Nasional. 